The Cryosphere Discuss., https://doi.org/10.5194/tc-2018-142

Manuscript under review for journal The Cryosphere

Discussion started: 7 August 2018

(c) Author(s) 2018. CC BY 4.0 License.

\author{
1 Anomalous acceleration of mass loss in the Greenland ice sheet \\ 2 drainage basins and its contribution to the sea level fingerprints \\ 3 during 2010-2012 \\ 4 Linsong Wang ${ }^{1,2}$, Liangjing Zhang ${ }^{2}$, Chao Chen ${ }^{1}$, Maik Thomas ${ }^{2,3}$, and Mikhail K. Kaban ${ }^{2}$ \\ 5 \\ $6{ }^{1}$ Hubei Subsurface Multi-scale Imaging Key Laboratory, Institute of Geophysics and Geomatics, China \\ 7 University of Geosciences, Wuhan 430074, China \\ $8 \quad{ }^{2}$ Helmholtz Centre Potsdam, GFZ German Research Centre for Geosciences, Telegrafenberg, Potsdam \\ 914473 , Germany \\ $10{ }^{3}$ Institute of Meteorology, Freie Universität Berlin, Berlin, Germany \\ 11 \\ Correspondence: Linsong Wang (wanglinsong@cug.edu.cn)
}

14 Abstract. The sea level rise contributed from ice sheet melting has been accelerating due to global warming. Continuous melting of the Greenland ice sheet (GrIS) is a major contributor to sea level rise, which impacts directly on the surface mass balance and the instantaneous elastic response of the solid Earth. To study the sea level fingerprints (SLF) caused by the anomalous acceleration of the mass loss in GrIS can help us to understand drivers of sea level changes due to global warming and the frequently abnormal climate events. In this study, we focus on the anomalous acceleration of the mass loss in GrIS at the drainage basins from 2010 to 2012 and on its contributions to SLF and relative sea level (RSL) changes based on self-attraction and loading effects. Using GRACE monthly gravity fields and surface mass balance (SMB) data spanning 13 years between 2003 and 2015, the spatial and temporal distribution of the ice sheet balance in Greenland is estimated by mascons fitting based on six extended drainage basins and matrix scaling factors. Then the SLF spatial variations are computed by solving the sea level equation. Our results indicate that the total ice sheet mass loss is contributed from few regions only in Greenland, 
The Cryosphere Discuss., https://doi.org/10.5194/tc-2018-142

Manuscript under review for journal The Cryosphere

Discussion started: 7 August 2018

(c) Author(s) 2018. CC BY 4.0 License.

29 i.e., from the northwest, central west, southwestern and southeastern parts. Especially

30 along the north-west coast and the south-east coast, ice was melting significantly

31 during 2010-2012. The total mass loss rates during 2003-2015 are $-288 \pm 7 \mathrm{Gt} / \mathrm{yr}$

32 and $-275 \pm 1 \mathrm{Gt} / \mathrm{yr}$ as derived from scaled GRACE data and SMB respectively; and

33 the magnitude of the trend increased to $-456 \pm 30 \mathrm{Gt} / \mathrm{yr}$ and to $-464 \pm 38 \mathrm{Gt} / \mathrm{yr}$

34 correspondingly over the period 2010-2012. The residuals obtained by GRACE after

35 removing SMB show a good agreement with the surface elevation change rates

36 derived from pervious ICESat results, which reflect a contribution from glacial

37 dynamics to the total ice mass changes. Melting of GrIS results in decreased RSL in

38 Scandinavia and North Europe, up to about $-0.6 \mathrm{~cm} / \mathrm{yr}$. The far-field peak increase

39 is less dependent on the precise pattern of self-attraction and loading; and the average

40 global RSL was raised by $0.07 \mathrm{~cm} / \mathrm{yr}$ only. Greenland contributes about $31 \%$ of the

41 total terrestrial water storage transferring to the sea level rise from 2003 to 2015 . We

42 also found that variations of the GrIS contribution to sea level have an opposite V

43 shape (i.e., from rising to falling) during 2010-2012, while a clear global mean sea

44 level drop also took place (i.e., from falling to rising).

45

46 Key words. GRACE; SMB; Greenland ice sheet; anomaly melting; sea level

47 fingerprints

48 
The Cryosphere Discuss., https://doi.org/10.5194/tc-2018-142

Manuscript under review for journal The Cryosphere

Discussion started: 7 August 2018

(c) Author(s) 2018. CC BY 4.0 License.

50 The sea level rise due to melting of ice sheets, glaciers and ice caps has been

51 accelerating in consequence of global warming. The mass change of polar ice sheets

52 is a major global concern, especially due to its direct impact to global sea level rise

53 (Forsberg et al., 2017). Estimation of the global ice balance has been obviously

54 improved in recent years based on available satellite observations, model simulations

55 and the development of data processing technologies, e.g., using the Gravity

56 Recovery and Climate Experiment (GRACE) (Rodell et al., 2009; Jacob et al., 2012;

57 Velicogna et al., 2014) and the Ice, Cloud, and land Elevation Satellite (ICESat)

58 (Zwally et al., 2011; Shepherd et al., 2012; Gardner et al., 2013). In the last decade,

59 most studies have confirmed that significant mass loss takes place in the ice sheets of

60 Greenland and Antarctica, which corresponds to approximately $7 \mathrm{~m}$ and $57 \mathrm{~m}$ of the

61 sea level rise respectively when the mass is completely melted (Bamber et al., 2001;

62 Lythe et al., 2001). Therefore, there is a high demand to monitor the trend in mass

63 balance changes over Greenland and Antarctica to better understand global climate

64 change and associated sea level rise.

65 Due to global warming, frequency and intensity of extreme weather events (i.e.,

66 snowstorms, cold currents, torrential rains, heat waves, etc.) are increasing globally.

67 Since the early 1990s, satellite data show that the global mean sea level has been

68 rising by about $3 \mathrm{~mm} / \mathrm{yr}$. Numerous scientific papers on ice sheet changes and their

69 contribution to sea level rise have been published based on satellite observations over

70 the last decade, but we still need to focus on the continental ice mass balance caused

71 by abnormal climate fluctuations in a short term period. A solitary wave disturbance

72 of global mean sea level has happened during 2010-2012, when the sea level

73 decreased by $5 \mathrm{~mm}$ from the beginning of 2010 to mid 2011 and then rose by nearly

$7420 \mathrm{~mm}$ until the end of 2012 (NASA: SEA LEVEL CHANGE Observations from

75 Space). This occurred along with a La Niña phase of the El Niño-Southern

76 Oscillation (ENSO). Previous studies have shown that the change in the sea level 
The Cryosphere Discuss., https://doi.org/10.5194/tc-2018-142

Manuscript under review for journal The Cryosphere

Discussion started: 7 August 2018

(c) Author(s) 2018. CC BY 4.0 License.

77 during La Niña is related to water temporarily moved from the oceans to the land,

78 when precipitation increased over Australia, northern South America, and Southeast

79 Asia, while it decreased over the oceans. Increased precipitation in Australia is proven

80 to be the dominant contributor to the global total sea level change in 2011 (Boening et

81 al., 2012; Fasullo et al., 2013).

82

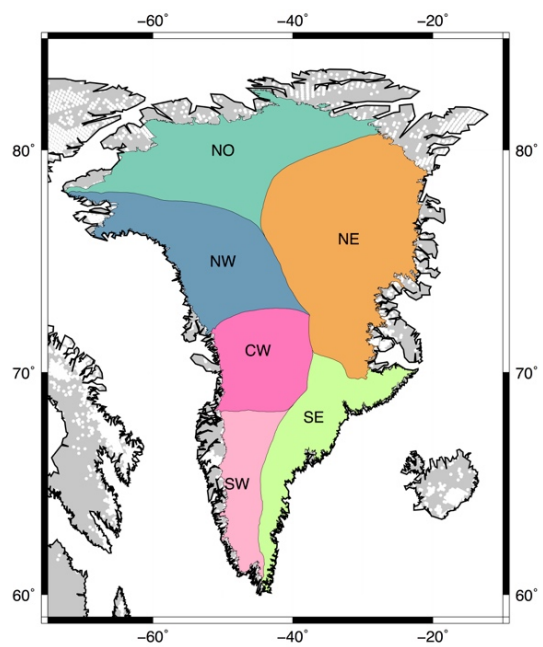

Figure 1. Greenland drainage basins. NO: north; NE: northeast; SE: southeast; SW: southwest; CW: central west and NW: northwest according to Rignot Basins from IMBIE 2016 (Rignot et al., 2011). White dots show ice caps in Greenland and surrounding areas.

83

84 It is well known that the Greenland ice sheet (GrIS) plays an important role in Earth system dynamics, which not only affects sea level but also contributes to the elastic response of the solid Earth. Here, we present detailed mass balance results for the

87 GrIS drainage basins by estimating the anomalous acceleration of the mass loss and 88 its contributions to sea level fingerprints (SLF). Figure 1 shows Greenland ice drainage units, named Rignot Basins from IMBIE 2016 (Ice Sheet Mass Balance Intercomparison Experiment), which are based on historical usage (Rignot et al.,

91 2011). The GrIS is divided into six regions based on the glacier regime. Central west 
The Cryosphere Discuss., https://doi.org/10.5194/tc-2018-142

Manuscript under review for journal The Cryosphere

Discussion started: 7 August 2018

(c) Author(s) 2018. CC BY 4.0 License. mark the transition from tidewater to land-terminating. Southeast vs northeast chiefly represents a transition in the surface mass balance (SMB) with a well-defined divide inland. We use GRACE monthly gravity fields and the monthly cumulative SMB from the Regional Atmospheric Climate Model (RACMO) to estimate the spatial distribution of the ice mass balance. The time series of mass changes were estimated by a mascon fitting method described by Jacob et al. (2012). The relative sea level (RSL) spatial variations were computed by solving the sea level equation with self-attraction and loading effects. Based on the above results, we further discuss the sensitivity kernels and rescaled GrIS time series due to the limitation of exact-defined basin mask and GRACE resolution; we also analyze spatial variations of the abnormal melting in glaciers, near-surface air temperature over Greenland and contributions of GrIS to sea level changes.

\section{Data and methods}

\subsection{GRACE}

The GRACE mission design makes it particularly useful for surface mass variations studies. GRACE was jointly launched by NASA and the German Aerospace Center (DLR) in March 2002 (Tapley et al. 2004). The Level-2 gravity products provide complete sets of spherical harmonic (Stokes) coefficients, typically up to the maximum degree/order $l_{\max }=120$, averaged over monthly intervals. Detection of mass change using GRACE data becomes a widely used tool for estimation of the ice sheet mass balance due to the operational difficulties of other measurements over large areas. However, interpretation of GRACE data is complicated by the intrinsic mixing of gravity signals. Glacial isostatic adjustment (GIA) can be corrected by modeling the lithospheric response to loading changes (Velicogna and Wahr, 2006) while other mass change contributions (e.g., terrestrial water storage) are smaller on ice sheets compared to other areas. 
The Cryosphere Discuss., https://doi.org/10.5194/tc-2018-142

Manuscript under review for journal The Cryosphere

Discussion started: 7 August 2018

(c) Author(s) 2018. CC BY 4.0 License.

120 In this study, we use monthly sets of spherical harmonics from the GRACE Release

12105 (RL05) gravity field solutions generated by the Center for Space Research (CSR)

122 at the University of Texas, spanning January 2003 to December 2015. Each monthly

123 GRACE field consists of a set of Stokes coefficients, $C_{l m}$ and $S_{l m}$, up to degree and

124 order $(l$ and $m)$ of 60 . We replaced the GRACE $\mathrm{C}_{20}$ coefficients with the results

125 inferred from satellite laser ranging (Cheng et al. 2013), and include degree-one

126 coefficients as calculated by Swenson et al. (2008). The Stokes coefficients from A et

127 al. (2013) are used to remove the GIA effect.

128

129

130

131

132

133

134

135

136

137

\subsection{SMB}

In several studies RACMO and the Firn Densification Model (FDM) have been applied for Greenland using different models at different resolutions and with various forcing at the boundaries. To further compare and validate the GRACE-derived mass changes, we use monthly SMB fields to simulate GrIS mass balance from RACMO version 2.3 (RACMO2.3), which are provided on a grid of about 40 vertical layers and a horizontal resolution of $\sim 11 \times 11 \mathrm{~km}^{2}$ for the period January 1958-December 2015 (Noël et al., 2015). Then we analyze the spatial and temporal patterns of glacial dynamics components combining GRACE and SMB data.
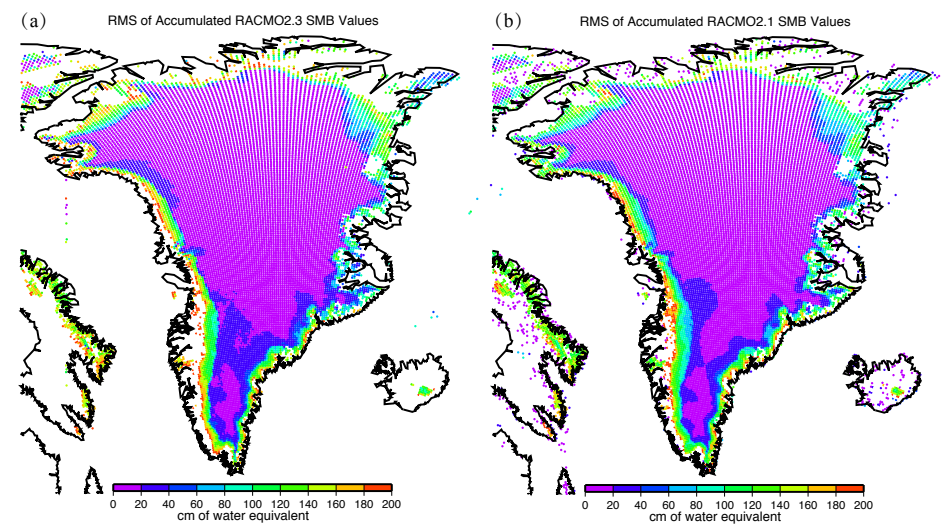

Figure 2. Root mean square errors of accumulated SMB values in RACMO2.3 (a) and RACMO2.1 (b) during 1960 to 2011. 
The Cryosphere Discuss., https://doi.org/10.5194/tc-2018-142

Manuscript under review for journal The Cryosphere

Discussion started: 7 August 2018

(c) Author(s) 2018. CC BY 4.0 License.

138 The latest version of RACMO2.3 has been specifically developed to simulate SMB of

139 glaciated regions as an updated version of RACMO2.1 (Ettema et al., 2009; Van

140 Angelen et al., 2014). Figure 2 shows root mean square errors of accumulated SMB

141 values in two versions for the period 1960 to 2011. Both models consist of 312

142 (latitude) $\times 306$ (longitude) grid cells and include Iceland, the Svalbard archipelago

143 and the Canadian Arctic. Overall, there is no significant difference in the cumulative

144 root mean square (1960-2011) between the two versions of the model, but

145 RACMO2.3 shows larger fluctuations at the boundary of GrIS. This is mainly due to

146 the fact that RACMO2.3 is forced at the lateral boundaries by the 40-year European

147 Centre for Medium-Range Weather Forecasts (ECMWF) Reanalysis (ERA-40) for the

148 period January 1958-December 1979 and the ECMWF Interim Reanalysis

149 (ERA-Interim) afterwards (van den Broeke et al., 2016).

150 In this study, we first used the GrIS mask as prescribed in RACMO2.3 to remove

151 effects of the ice caps from entire SMB in Greenland and integrated them over time to

152 get accumulated SMB values. Because SMB represents the sum of mass fluxes inside

153 and away from ice sheets, the mass balance of the grounded ice sheet is governed by

154 the difference between SMB and the solid ice discharge across the grounding line.

155 Thus, the ice discharge must be subtracted from the accumulated SMB (SMB minus

156 ice discharge) to be compared with GRACE (van den Broeke et al., 2016). After

157 removing the temporal average of the accumulation rates at each point, we convert

158 SMB data to the spectral domain and truncate them to degree 60 , i.e., the limit of the

159 GRACE data.

$160 \quad 2.3$ Other datasets

161 Initially, we employed the Noah land hydrology model (version 2) in the Global Land

162 Data Assimilation System (GLDAS-2) to remove continental water mass

163 contributions, but we found that there is a large error in the results. The global

164 GLDAS/Noah, which possesses monthly intervals with a spatial resolution of 1.0

165 degree, provides a total amount of the water stored in all layers, snow, and canopy, but 
The Cryosphere Discuss., https://doi.org/10.5194/tc-2018-142

Manuscript under review for journal The Cryosphere

Discussion started: 7 August 2018

(c) Author(s) 2018. CC BY 4.0 License.

does not include the groundwater and water storage changes in rivers or lakes (Rodell

167 et al., 2004). It also excludes the water storage estimates from the GrIS and

168 permafrost areas (Liu et al., 2016). Likely, the abnormally large snow values obtained

169 for Greenland are a result of unreliable forcing data. We simulated mass changes from

170 the soil moisture component and found that the soil moisture from GLDAS is

171 dominated by the annual cycle and the annual amplitudes are much smaller than the

172 GrIS change. Finally, we ignored the terrestrial water storage (e.g., mainly presented

173 as seasonal changes, no obvious long-term trend) impacts on the mass change in

174 Greenland and assumed that the mass balance revealed by GRACE data is mainly due

175 to ice sheet changes.

176 A previous study based on satellite-derived ice-surface temperature has confirmed a

177 positive trend of the near surface temperature of GrIS and two major melt events from

1782000 to present (Hall et al., 2013). Therefore, we chose the temperature data from the

179 GLDAS/Noah model, which integrates the latest NASA remote sensing products (e.g.,

180 moderate-resolution imaging spectro-radiometer, MODIS). We investigated whether

181 there was clear correlation in spatial distribution of the GLDAS/Noah forcing data

182 (i.e., temperature) and the GrIS variations spanning from 2003 to 2015.

183 On climate timescales, the global mean sea level rise is mainly caused by increasing

184 volume of the global ocean in consequences of thermal expansion) and increasing

185 ocean mass due to water masses from land (i.e., GRACE-derived barystatic sea level

186 rise caused by loss of ice and reduction of liquid water storage on land). Reliable time

187 series of global mean sea level based on satellite altimetry (TOPEX/Poseidon, Jason-1

188 and OSTM/Jason-2) are available since September 1992 (the global mean sea level

189 data was downloaded from NASA, available at:

$190 \mathrm{https}: / /$ sealevel.nasa.gov/understanding-sea-level/key-indicators/global-mean-sea-leve

191 1). All biases and cross-calibrations have been applied to the data, therefore sea

192 surface height anomalies derived from various altimetry missions are expected to be

193 consistent. The data have been presented as changes relative to January 1, 1993 
The Cryosphere Discuss., https://doi.org/10.5194/tc-2018-142

Manuscript under review for journal The Cryosphere

Discussion started: 7 August 2018

(c) Author(s) 2018. CC BY 4.0 License.

194 averaged over 2-months intervals. The GIA correction has been applied to the data

195 (Beckley et al., 2017). To estimate steric sea level anomalies, we used time series of

196 3-month total steric sea level anomaly data, which is a contribution of the changes in

197 the global ocean heat storage for the $0-700 \mathrm{~m}$ and 0-2000 $\mathrm{m}$ layers (the total steric

198 sea level anomaly data was downloaded from NOAA, available at:

199 https://www.nodc.noaa.gov/OC5/3M_HEAT_CONTENT/basin_fsl_data.html).

$200 \quad 2.4$ Spatial Averaging and scaling factor methods

201 Observations of mass variability are, in particular, useful for estimates of changes of continental water storage. These water storage changes are generally addressed by constructing specific averaging functions optimized for each region (Swenson and Wahr, 2002). Note that the averaging kernel method implies a Gaussian averaging

205 function at each point, and sums those averaging functions expressed as the finite number of harmonic degrees in the GRACE solution (e.g. $l_{\max }=60$ for CSR solutions). Thus, the optimal averaging kernel technique provides an estimate of the total mass change of the region but does not give accurate estimates of sub-regions, such as those in Figure 1, due to the spatial resolution of the GRACE data. Therefore, the effect of mass changes is spread up to several hundred kilometers outside the region.

(a)

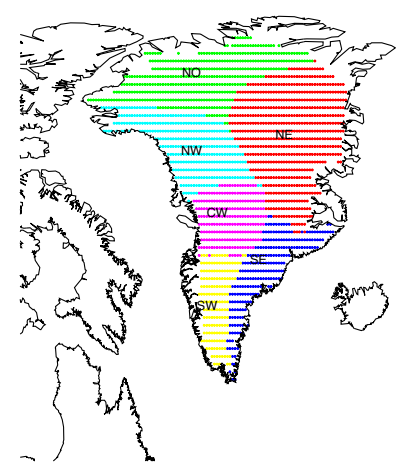

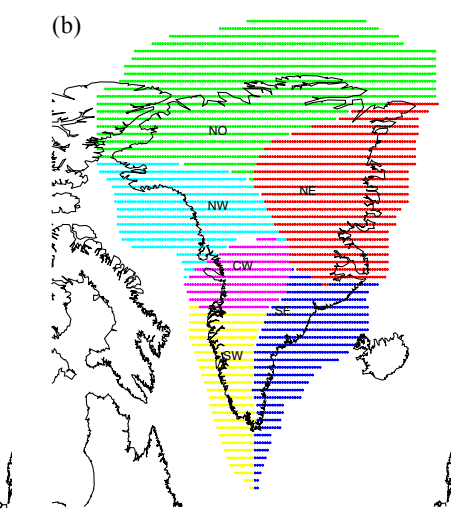

Figure 3. Mascons for the GrIS drainage basins (a). Each colored region represents a single mascon. (b) similar to Figure 3a but for the extended mask of six mascons. 
The Cryosphere Discuss., https://doi.org/10.5194/tc-2018-142

Manuscript under review for journal The Cryosphere

Discussion started: 7 August 2018

(c) Author(s) 2018. CC BY 4.0 License.

212 In this case, we applied an approximation mascon fitting method to GRACE and

213 SMB data to perform a comparison at the regional level. This fitting method is based

214 on the least squares mascon approach to calculate the averaged time series for each

215 region (Jacob et al., 2012; Sutterley et al., 2014). To evaluate the spatial differences in

216 the melting of GrIS at a regional scale, we divided the ice sheet into six extended

217 mascons as shown in Figure 3, and each mascon was composed of small blocks

218 defined on a 0.5 -degree grid; a unit mass equal to $1 \mathrm{~cm}$ of water was distributed

219 uniformly over the block (Farrell 1972). We applied a 150-km Gaussian smoothing

220 function on the Stokes coefficients for the GRACE (GIA corrected), SMB and all

221 mascon coefficients.

222 We simultaneously fit the extended mascon Stokes coefficients, in which GrIS is

223 represented by a single basin, to monthly GRACE coefficients (after post-processing

224 described in section 2.1) to obtain estimates of monthly mass variability for each

225 mascon. The corresponding result in terms of time series of entire GrIS is shown in

226 Figure 4. When using extended mascons, the mass loss is assumed to be uniformly

227 distributed over mascons, which is not the case everywhere (e.g., because there is no

228 or relatively small mass change over the oceans). Thus, it is necessary to identify a

229 realistic scaling factor. Assuming that there is a $1 \mathrm{~cm}$ uniform layer over exact and

230 extended GrIS, the total mass is $17.495 \mathrm{Gt}$ and $39.303 \mathrm{Gt}$, respectively. We used the

231 exact Greenland mascon as the input to fit the extended mascon to the input signal. In

232 this way, the $0.537 \mathrm{~cm}$ uniform mass is obtained over the extended GrIS, which is

233 equivalent to a $46 \%$ reduction in ice thickness of the input mass, which is in good

234 agreement with previous studies based on averaging functions extended outside

235 Greenland (Velicogna and Wahr, 2006). The final scaling factor of the mass inferred is

$236(39.303 / 17.495) \times 0.537=1.206$. Therefore, the mass changes estimated with the

237 extended mascon are larger by a factor of 1.206 when degree and order of Stokes

238 coefficients are limited to 60 (Figure 4). 
The Cryosphere Discuss., https://doi.org/10.5194/tc-2018-142

Manuscript under review for journal The Cryosphere

Discussion started: 7 August 2018

(c) Author(s) 2018. CC BY 4.0 License.

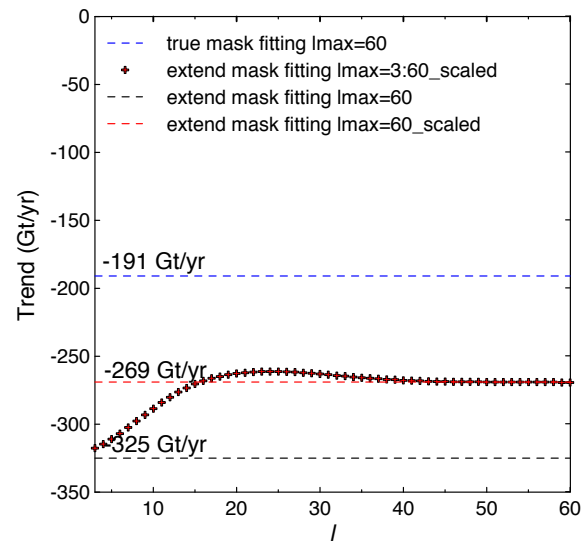

Figure 4. Time series for the entire GrIS from the exact and extended mascons to fit monthly GRACE coefficients. Red crosses are scaled extended mascon fitting results due to change of the scale factor for different degree $(l)$.

We take into account the fact that the effect of each mascon could smear into the neighboring ones. Supposing that the mass spread is uniform over the truly mascon $_{i \text {, }}$ we computed the Stokes coefficients from the input mass, and then fit extended mascon $_{k}$ to the set of Stokes coefficients. Basing on the scaling method described above, those values can be used to construct a ratio matrix $A(k, j)$, which is the contribution of those Stokes coefficients to the result for mascon $_{k}$. Time series for selected regions were calculated using the corresponding mascons to fit GRACE

248 Stokes coefficients. If $M(j)$ are the true mascon values, and $N(k)$ are the values that we 249 get from the mascon fitting, then the linear observation equations is $N(k)=$ $250 \sum_{j=1}^{6} A(k, j) \times M(j)$. Therefore, the true mascon values may be solved in a generalized 251 inversion by $M(j)=A^{-1}(k, j) \times N$. This method not only estimates the total mass 252 change but also provides time series for each sub-area after the leakage correction. 253 However, it is worth noting that the extended mascon increases the weight of the 254 boundary in the sensitivity kernels and also causes external leakage in the fitting results, e.g., mass change from the external glaciers, ice caps and eustatic sea level. 
The Cryosphere Discuss., https://doi.org/10.5194/tc-2018-142

Manuscript under review for journal The Cryosphere

Discussion started: 7 August 2018

(c) Author(s) 2018. CC BY 4.0 License.

256 The sensitivity kernels and leakage effects are explained in details in Section 4.1.

$257 \quad 2.5$ Sea level fingerprint

258 The global SLF reflects the redistribution of ocean-land masses driven by climate

259 change; and these load changes cause the elastic structural response of the crust and

260 affect the viscosity and strength of the lower mantle of the Earth (Peltier and Andrews,

261 1976). RSL changes, for instance, caused by GIA span over a time scale of 1 to 10000

262 years. However, for shorter time scales (1 to 100 years), melting of ice sheets, glaciers

263 and ice caps directly leads to increase of ocean volume and causes instantaneous

264 elastic deformation of the solid Earth. RSL is the height of the sea surface relative to

265 the sea floor, which is defined as the difference between the geoid and the crust. The

266 RSL solution is often referred as the fingerprint of terrestrial mass changes.

267 In this study we use scaled monthly ( 1 degree $\times 1$ degree $)$ mass change grids of GrIS

268 as input to solve the self-consistent sea level equation (Farrell and Clark, 1976; Milne

269 et al., 1999) and calculate regional SLF due to self-attraction and loading effects

270 (Tamisiea, 2010) of mass changes on Greenland. We use the load Love numbers given

271 by Jentzsch (1997), which were calculated using the 1-D PREM elastic Earth model

272 (Dziewonski and Anderson, 1981). We also consider the Earth rotation feedback but

273 neglect changes in the coastline and effects of atmospheric and non-tidal ocean

274 loading for short-term sea level variations during 2003 to 2015.

275

2763 Results

$277 \quad 3.1$ Spatial GrIS variability

278 The spatial pattern of long-term mass trend, shown in Figure 5, was obtained from the

279 monthly GRACE mass solutions for Greenland from 2003 to 2009 (a), 2010 to 2012

280 (b), 2013 to 2015 (c) and 2003 to 2015 (d). A clear negative trend was identified

281 across the entire ice sheet except in high altitude areas $(>2000 \mathrm{~m})$ in the central part.

282 During 2003-2015, the mass loss increased in northwest, central west, south west and

283 southeast, especially along the north-west coast and the south-east coast. In the north 
The Cryosphere Discuss., https://doi.org/10.5194/tc-2018-142

Manuscript under review for journal The Cryosphere

Discussion started: 7 August 2018

(c) Author(s) 2018. CC BY 4.0 License.

284 and northeast, the mass melted relatively slowly compared to the other four areas. The

285 ice mass loss increased in 2010-2012 and 2013-2015 relative to 2003-2009.

286 Especially important is that during 2010-2012 a large mass loss is revealed in the entire southern and western regions of Greenland (Figure 5b), which reflects a major melting event that took place in this period. For example, the anomalous warm summer and declined albedos associated with the north Atlantic oscillation led to

290 increased temperatures over Greenland in 2010 (Box et al., 2012). Consequently, the

291 extreme melt event took place over almost the entire surface of the GrIS in 2012

(Nghiem et al. 2012).
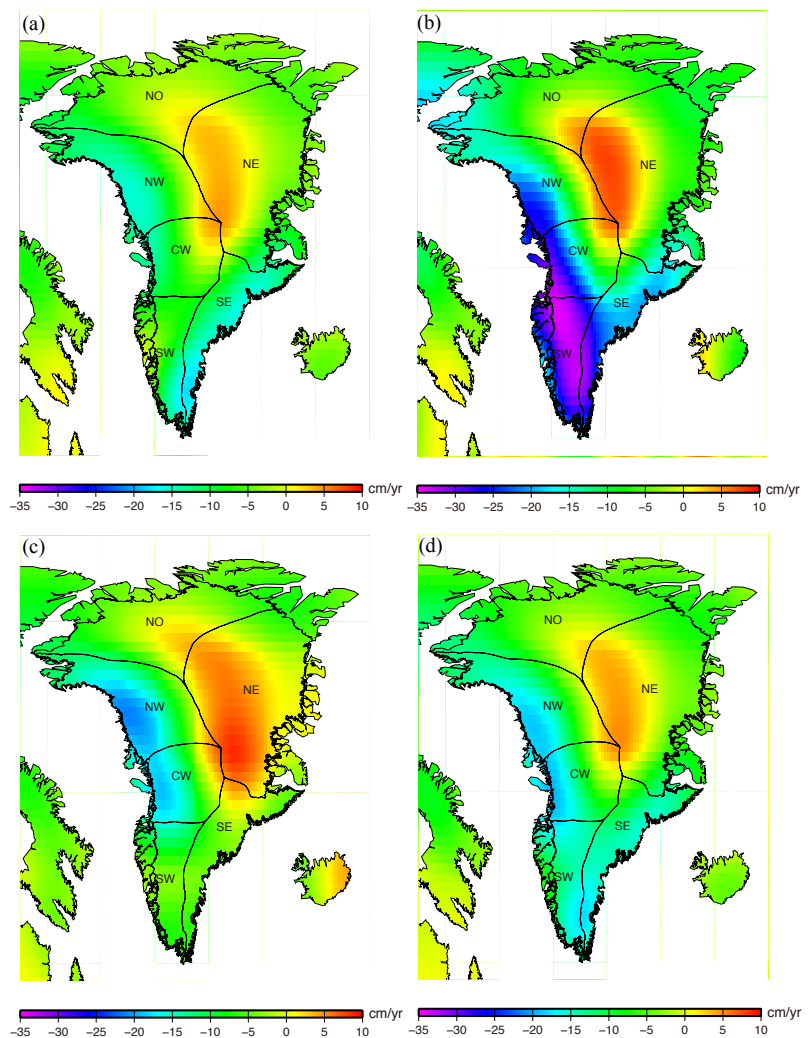

Figure 5. GRACE-derived linear trends of GrIS ice mass balance in 2003-2009 (a),

2010-2012 (b), 2013-2015 (c) and 2003-2015 (d). 
The Cryosphere Discuss., https://doi.org/10.5194/tc-2018-142

Manuscript under review for journal The Cryosphere

Discussion started: 7 August 2018

(c) Author(s) 2018. CC BY 4.0 License.

295 Figure 6 shows spatial patterns of ice mass changes from SMB data. In 2003-2015,

296 the SMB results indicate that ice mass loss and thinning was concentrated in the entire

297 coastline as well as in western and southeast basins of Greenland. In 2010-2012, mass

298 loss and thinning were stronger in the northwest, central west, south west and

299 southeast; and this spatial and temporal distribution is very consistent with the

300 GRACE-derived mass loss. However, the trend magnitude of SMB is smaller than of

301 the GRACE results. Additionally, we shall keep in mind that the GRACE-derived

302 results reflect mass changes of both SMB and ice discharge, e.g., beginning at 1995,

303 SMB decreased while ice discharge increased, due to acceleration of the ice melting

304 in several large outlet glaciers in the southeast and northwest, which leading to a

305 quasi-persistent negative mass balance (van den Broeke et al., 2016). Moreover,

306 because of large runoff and surface mass fluxes (i.e., meltwater and snowfalls) at the

307 boundary of the GrIS, the current horizontal resolution of RACMO2.3 $(11 \mathrm{~km})$ is

308 insufficient to resolve individual, low-lying outlet glaciers of the GrIS (Noël et al.,

309 2016), which leads to potentially large errors and uncertainties in accumulated SMB

310 values (Figure 2).
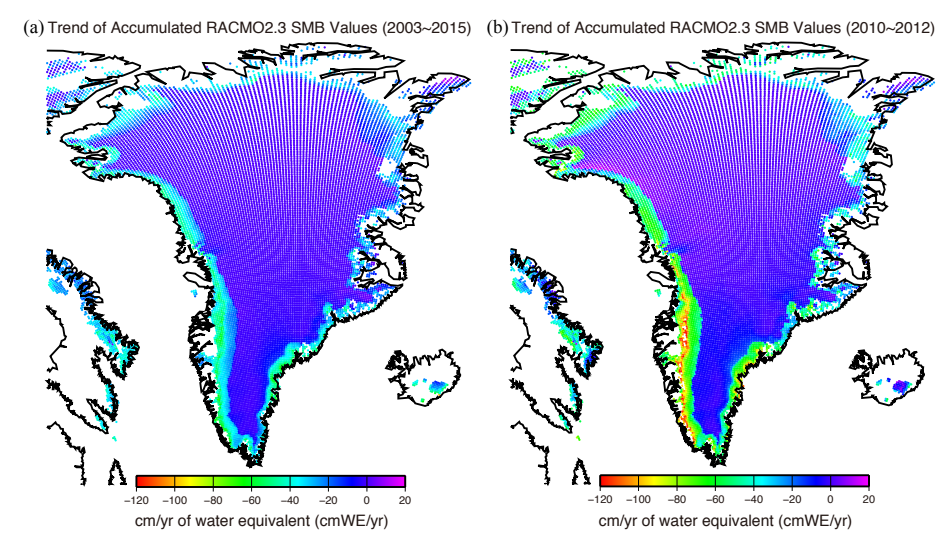

Figure 6. $\mathrm{SMB}$ trend in millimeter water equivalent per year or (mmWE/yr) obtained from the RACMO2.3 monthly SMB fields. (a) 2003 to 2015 and (b) 2010 to 2012 . 
The Cryosphere Discuss., https://doi.org/10.5194/tc-2018-142

Manuscript under review for journal The Cryosphere

Discussion started: 7 August 2018

(c) Author(s) 2018. CC BY 4.0 License.

313 In order to obtain time series of GrIS mass changes we applied the basin estimation

314 and scaling method described in Section 2 (Figure 7). Representing GrIS by single and extended mascons, we found that the scaled trend rate $\left(-269 \mathrm{Gt} / \mathrm{yr}\right.$ when $l_{\max }=60$ shown in Figure 4) from 2003 to 2015 in the whole GrIS region is in good agreement with that reported by $-270 \mathrm{Gt} / \mathrm{yr}$ during 2003-2012 (Schrama et al., 2014) and -270 Gt/yr during 2003-2014 (van den Broeke et al., 2016). When the GrIS is represented by six extended basins, the results also show a continuous decrease both before and after scaling (top and bottom left in Figure 7) from 2003 to 2015; since 2010, the rate of this decrease suddenly accelerated towards the end of 2012. The rate of the mass loss obtained by scaled GRACE and SMB is also similar, $-288 \pm 7 \mathrm{Gt} / \mathrm{yr}$ in GRACE and $-275 \pm 1 \mathrm{Gt} / \mathrm{yr}$ in SMB from 2003 to 2015. The magnitude of the trend increased significantly over the period 2010-2012, about $-456 \pm 30 \mathrm{Gt} / \mathrm{yr}$ in GRACE and $464 \pm 38 \mathrm{Gt} / \mathrm{yr}$ in SMB. The errors here represent fitting uncertainties, while the real uncertainties are mainly due to the GIA correction, leakage of signal from outside ice sheet, and GRACE measurement errors. Those effects in the trends were estimated to be $20 \mathrm{Gt} / \mathrm{yr}$ in both time series (Van den Broeke et al., 2009). Our estimates are in good agreement with the magnitude of the fitted linear trend both from GRACE and

330 SMB over the period 2003-2014 (van den Broeke et al., 2016) but slightly larger than 331 the reported GRACE-derived mass loss rate from Sutterley et al. (2014), Velicogna et 332 al. (2014) and Forsberg (2017). It should be noted that the overestimation of our 333 results likely comes from the leakage effect of glaciers and ice caps due to the fact 334 that we used extended mascons to fit the GRACE and SMB data. The impact of this 335 part may reach about 20 80 Gt/yr (Bolsch et al. 2013; Velicogna et al., 2013). 
The Cryosphere Discuss., https://doi.org/10.5194/tc-2018-142

Manuscript under review for journal The Cryosphere

Discussion started: 7 August 2018

(c) Author(s) 2018. CC BY 4.0 License.
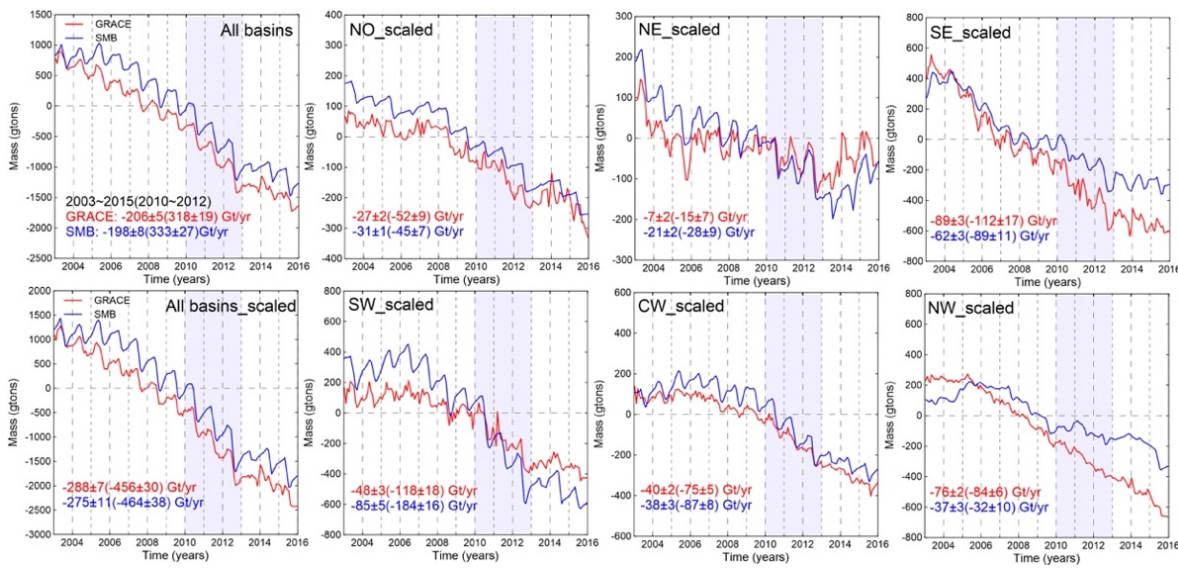

Figure 7. Ice mass change in gigatons (gtons) for GrIS, the top part of the figure from left to right is from the exact mascons of GrIS, extended mascons (after scaled) of NO, NE and SE, respectively. The lower part of the figure from left to right is from the extended mascons (scaled) of GrIS, SW, CW and NW, respectively. GRACE time series for January 2003 to December 2015 (red), time series of cumulative SMB anomaly for January 2003 to December 2015 (blue). Light blue bands represent the time span from January 2010 to December 2012.

For GrIS drainage basins at the regional scale, the melting rate of GrIS in the southern part is significantly higher than in the northern part. The mass loss in the north and northeast was less than $-31 \mathrm{Gt} / \mathrm{yr}$ for both GRACE and SMB during 2003-2015, and the mass loss of the other four basins (i.e., northwest, central west, south west and southeast) were several times larger than the ones in the two northern regions. The time series of GRACE and SMB revealed that almost all regions experienced large mass losses in 2010-2012. In the southwest and southeast, we found an anomalous acceleration of the mass loss of $-118 \pm 18 \mathrm{Gt} / \mathrm{yr}$ and $-112 \pm 17 \mathrm{Gt} / \mathrm{yr}$ in GRACE and $184 \pm 16 \mathrm{Gt} / \mathrm{yr}$ and $-89 \pm 11 \mathrm{Gt} / \mathrm{yr}$ in SMB, respectively. The contribution of these two regions is responsible for about $50 \%$ of the total loss. In addition, we also found that the melting rate of ice sheets from SMB was greater than the estimates derived from 
The Cryosphere Discuss., https://doi.org/10.5194/tc-2018-142

Manuscript under review for journal The Cryosphere

Discussion started: 7 August 2018

(c) Author(s) 2018. CC BY 4.0 License.

overestimate ice mass changes, since the modeled surface meltwater increases strongly with decreasing elevation and latitude in the low-lying parts of the southwestern GrIS (van den Broeke et al., 2016). In addition, the surface ice elevation was changed by fast-flowing ice dynamics in the southwestern and northeastern areas

354 (Hurkmans et al., 2014). Since 2013, the mass loss slowed down and recovered in the

355 GrIS drainage basins. The agreement between GRACE and SMB results also confirm

356 that the ice sheets returned to near-normal melt conditions, i.e., the refreezing process

357 reduced the melt extent back to normal conditions (Nghiem et al., 2012).

358

359
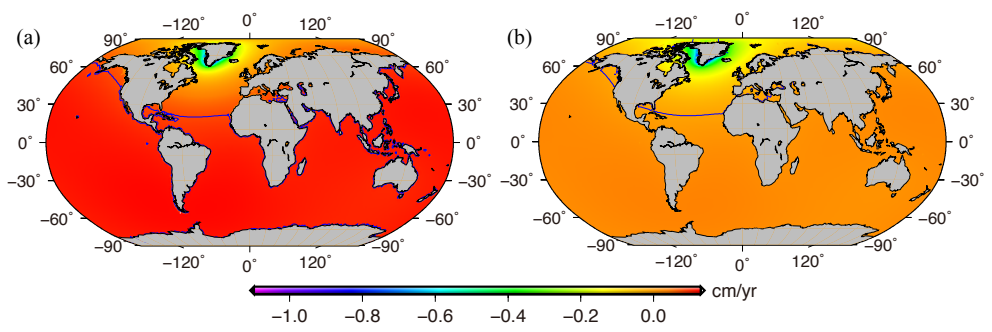

Figure 8. Trends in the sea level fingerprint (SLF) due to mass change of GrIS (a). (b) contributions from the Earth's elastic response. Trends are calculated for the time period January 2003 to December 2015. Blue contour in Figures 8a and 8b is the mean RSL or barystatic sea level equivalent. 
The Cryosphere Discuss., https://doi.org/10.5194/tc-2018-142

Manuscript under review for journal The Cryosphere

Discussion started: 7 August 2018

(c) Author(s) 2018. CC BY 4.0 License.

370 Due to ice sheet melting, the sea level along coastlines located up to 2000 kilometers

371 away falls as a result of the isostatic uplift of the crust. The escaping seawater flows

372 across the equator, i.e., the melting of Greenland impacts the coastline of Brazil and

373 the melting of Antarctica affects the United States. These regional differences are

374 significant if we consider the global melting of ice sheets, glaciers and ice caps. For

375 instance, the amount of ice mass melt in the northern hemisphere is higher than in the

376 southern hemisphere, resulting in apparent RSL rise in the South America, South

377 Africa, and Australia, what is nearly 30\% higher than the global mean sea level rise

378 rate (Mitrovica et al., 2001; Bamber et al., 2009). In addition, induced by the mass

379 loss of GrIS, the mean RSL trend is approximately $0.07 \mathrm{~cm} / \mathrm{yr}$ extending through

380 Alaska, Mexico and northern Africa (solid blue line in Figure 8). This pattern

381 illustrates that the dynamic sea level change is determined by the ocean-land mass

382 redistribution and by the instantaneous elastic response of the lithosphere.

\section{Discussions}

\section{$385 \quad 4.1$ Sensitivity kernels and rescaling}

386 As an example of the averaging kernel, Figure 9 shows the sum of the sensitivity kernels for all exact and extended mascons shown in Figure 3. Ideally, the solution for mascon fitting would recover the true spatial average of the mascons' mass. When mascons are fitted for the exact-defined GrIS drainage sub-areas (Fig. 3a), the results are automatically scaled. The effective scaling factor based on the least squares mascon approach is defined assuming that surface masses are spread uniformly across any mascon. This method will give exactly the right total mass for that mascon, and will give 0 for the other mascons. However, similar to the optimal averaging kernel method, the mascon fitting based on an exact-defined basin mask (i.e., truly six drainage basins) will also cause weakening of the signal or large uncertainty (e.g., leakage and bias). This is especially the case in boundary areas, which largely contribute to the mass loss, because of the finite number of harmonic degrees in the 
The Cryosphere Discuss., https://doi.org/10.5194/tc-2018-142

Manuscript under review for journal The Cryosphere

Discussion started: 7 August 2018

(c) Author(s) 2018. CC BY 4.0 License.

398 GRACE solution. Previous studies suggest that an increasing of the number of 399 mascons covering the anomaly might reduce leakage, so that the anomaly is almost 400 constant across each individual mascon (Jacob et al., 2012). However, there are also 401 indications that using more and smaller mascons can lead to the drawback that the 402 inversion relies more on the higher harmonic degrees.

403 For six sub-areas of the extended mascon (Figure 9b), we assessed a potential impact 404 of the non-uniformity over the exact mascons and external mascons. For the leakage 405 effects, we first computed the mascon distribution between sub-regions, and then we 406 obtained the scale factors by fitting the six extended mascons to the corresponding 407 exact mascons (Table 1). To confirm the validity of signal recovery based on this 408 scaling method, we also used two different regional average methods to compare the 409 results. One method represents a data-driven approach, which is able to restore the 410 GRACE signal loss due to filtering independent of the catchment size (Vishwakarma 411 et al., 2016; 2017). Another method implies scaled optimal averaging functions to 412 recover unbiased mass estimates for six basins (Velicogna and Wahr, 2006).

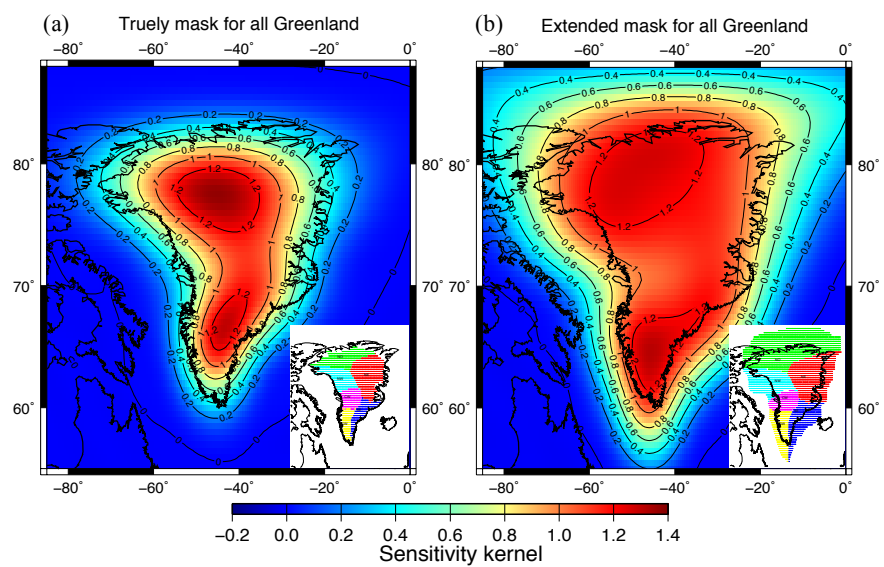

Figure 9. Sensitivity kernel for the truly mask (a) and extended mask (b) of all drainage basins. 
The Cryosphere Discuss., https://doi.org/10.5194/tc-2018-142

Manuscript under review for journal The Cryosphere

Discussion started: 7 August 2018

(c) Author(s) 2018. CC BY 4.0 License.

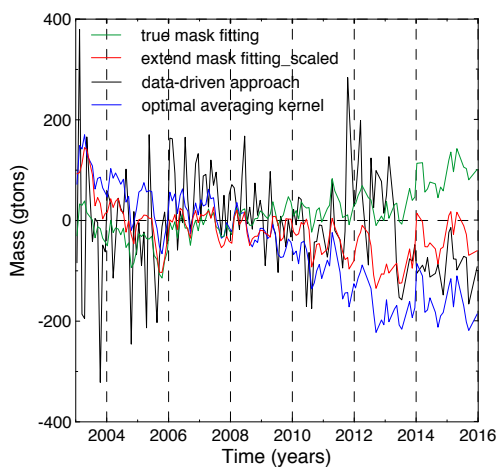

Figure 10. Time series of the true mask fitting mascon and scaled extended mascon fitting in the northeast accompanied by the regional average based on the optimal averaging kernel and data-driven approach.

415

Exemplarily, Figure 10 shows a validation with the time series comparison between the results from the exact mascon fitting and the extended mascon fitting after rescaling in the northeast. The results confirm that the exact mascon fitting cannot accurately extract the melting contribution of glaciers close to the border (i.e., sensitivity kernel less than 1 shown in Figure 9a). Consequently, the time series from the exact mascon fitting in the northeast show an increasing trend, what is inconsistent with the actual situation and contradicts most previous studies (Velicogna et al., 2014; Sutterley et al., 2014). In addition, the time series obtained by the other two methods also confirm the mass loss trend of ice sheets in the northeast. However, the optimal averaging kernel after scaling may include leakage in other regions and a data-driven approach shows a large noise error in the time series. This is mainly due to the fact that the optimal averaging kernels were created to isolate the gravity signal of individual regions while simultaneously minimizing the effects of GRACE observational errors and contamination from dynamic changes of nearby glaciers (Swenson and Wahr, 2002). Though, this method cannot prevent leakage from adjacent areas. Therefore, there still exists large signal loss in each region due to the filtering and truncation of GRACE coefficients. A data-driven approach was 
The Cryosphere Discuss., https://doi.org/10.5194/tc-2018-142

Manuscript under review for journal The Cryosphere

Discussion started: 7 August 2018

(c) Author(s) 2018. CC BY 4.0 License.

433 developed to extract leakage information from the filtered versions of the field, but

434 this method also suffers several limitations, e.g., it does not work with sufficient

435 accuracy for active catchments, and both the scaling factors and the aggregated noise

436

over catchments increase as the catchment size decreases (Vishwakarma et al., 2016).

437

438 Table 1. Scale factors of six basins derived with the extended fitting approach

\begin{tabular}{ccccccc}
\hline & NO & NE & SE & SW & CW & NW \\
\hline NO_extended & 0.952 & 0.014 & 0.000 & 0.011 & -0.005 & 0.062 \\
NE_extended & 0.126 & 1.063 & 0.059 & -0.031 & 0.056 & 0.112 \\
SE_extended & -0.007 & -0.021 & 0.954 & 0.190 & 0.071 & -0.013 \\
SW_extended & 0.012 & -0.003 & 0.071 & 0.960 & -0.098 & -0.012 \\
CW_extended & -0.042 & 0.036 & 0.151 & 0.136 & 1.045 & 0.050 \\
NW_extended & 0.181 & 0.049 & -0.039 & -0.033 & -0.008 & 0.964 \\
Ratio of total mass to input mass & 1.223 & 1.138 & 1.196 & 1.235 & 1.061 & 1.163 \\
\hline
\end{tabular}

439

$440 \quad 4.2$ Spatial differences of abnormal melting in glacier dynamics

441 If we ignore the GIA correction error, total mass changes detected by GRACE contain

442 a component caused by changes in SMB (corrected ice discharge) and a component

443 caused by ice dynamics. Usually, the latter can be estimated from satellite altimetry

444 data. Thus, the residuals obtained from GRACE after removing SMB may well reflect

445 glacial dynamics. Figure 11 shows the residuals for each drainage basin and the entire

446 GrIS, which is used to interpret the contribution from glacial dynamics to total ice

447 mass changes. The time series for six drainage basins are quite different and show no

448 overall trend characteristics in GrIS. In the southeast and northwest, there is a

449 negative trend in the difference GRACE minus SMB. Global navigational satellite

450 system data also revealed intense Greenland melting. For example, crustal motion

451 data show that solitary seasonal waves are associated with substantial mass transport

452 through the Rink Glacier in 2010 and 2012 (Adhikari et al., 2017). In contrast, a 
The Cryosphere Discuss., https://doi.org/10.5194/tc-2018-142

Manuscript under review for journal The Cryosphere

Discussion started: 7 August 2018

(c) Author(s) 2018. CC BY 4.0 License.

453 positive rate of mass change is found in southwest and northeast areas. In central west, 454 north and entire Greenland, the time series of the residuals do not have apparent

455 trends. This spatial difference is in a good agreement with surface elevation changes derived from ICESat, GRACE and GPS data based on previous results (Howat et al., 2008; Khan et al., 2010; Hurkmans et al., 2014). Particularly, satellite observations such as the Oceansat-2 satellite, MODIS and Special Sensor Microwave Imager/Sounder reveal that melt occurred at or near the surface of GrIS across $98.6 \%$ of its surface on 12 July 2012 (Nghiem et al., 2012).
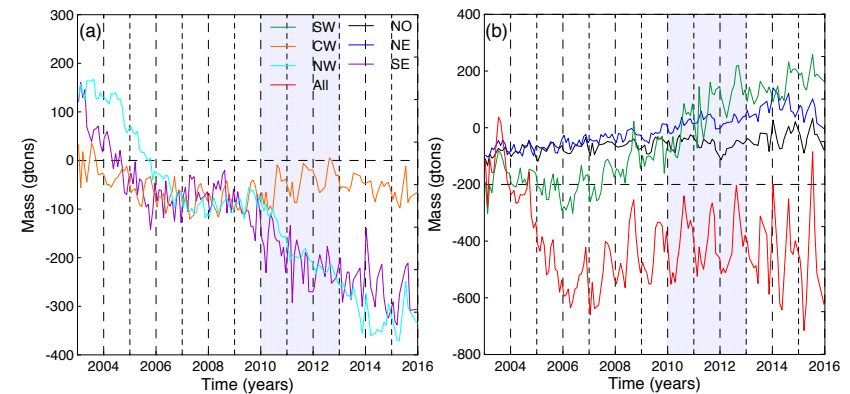

Figure 11. Residuals obtained from GRACE after removing SMB for each drainage basin and the entire GrIS.

462

463

464

Because of the combination of the modelled (SMB) and observed (GRACE) data, any uncertainty or error of the data source will appear in the residuals. Based on the mass budget method, the SMB model estimates the difference between individual mass sources (mainly snowfall) and sinks (mainly meltwater runoff and solid ice discharge) (van den Broeke et al., 2016). The accumulation/ablation zones of an ice sheet are largely driven by changes in weather conditions (Hanna et al., 2011). More importantly, glacial dynamics refer to the flow of ice from the interior of the ice sheet outward through outlet and land-terminating glaciers (Liu et al., 2016). Although this kind of ice discharge may not be accurately estimated by the SMB model, its contribution to the total mass balance cannot be ignored either. Another factor 
The Cryosphere Discuss., https://doi.org/10.5194/tc-2018-142

Manuscript under review for journal The Cryosphere

Discussion started: 7 August 2018

(c) Author(s) 2018. CC BY 4.0 License.

473 influencing the residual is the accuracy and limited resolution of GRACE data, e.g.,

474 measurement errors, GIA correction, leakage effects from outside the ice sheet and the

475 eustatic sea level, etc. For Greenland the uncertainties in the GRACE estimates of the

476 ice sheet mass balance have been analyzed in previous studies (Van den Broeke et al.,

477 2009; Bolsch et al. 2013; Velicogna and Wahr, 2013). Therefore, we will not discuss

478 them here in detail. At the same time, we are aware that the errors come mostly from

479 the uncertainty in the scaling factor due to partitioning of GrIS into six mascons. The

480 difference between the non-uniform distribution of actual ice sheets and our

481 assumption of uniform mass distribution within the basin or each mascon also leads to

482 uncertainty of the scaling factor, which increases the uncertainty of final mass loss

483 estimates.

$484 \quad 4.3$ Near-surface air temperature over the Greenland

485 In general, mass changes of the GrIS mainly depend on temperature variations, which

486 cause both ice discharge and surface meltwater runoff. Near-surface temperatures can

487 be derived from global land surface models forced with atmospheric data (e.g.,

488 Satellite-derived MODIS data in this study) (Syed et al. 2008). Figure 12 shows the

489 averaged near-surface air temperatures from the GLDAS forcing (i.e, MODIS) data in

490 Greenland for the periods 2003-2015 (Figure 12a) and 2010-2012 after removing

491 the average of 2003-2015 (Figure 12b). The spatial distribution of the temperature

492 anomalies indicates that the increased mass loss rate from GRACE observations and

493 SMB simulations is mainly due to relatively high surface temperature of South

494 Greenland (i.e., mean change range from about -10 to $-5{ }^{\circ} \mathrm{C}$, Figure $5 \mathrm{~d}$ and Figure

495 6a). According to Figure 12b, there are large positive temperature anomalies over

496 most parts of Greenland during 2010-2012, which is consistent with the acceleration

497 of mass loss in the GrIS during the same period.

498 
The Cryosphere Discuss., https://doi.org/10.5194/tc-2018-142

Manuscript under review for journal The Cryosphere

Discussion started: 7 August 2018

(c) Author(s) 2018. CC BY 4.0 License.

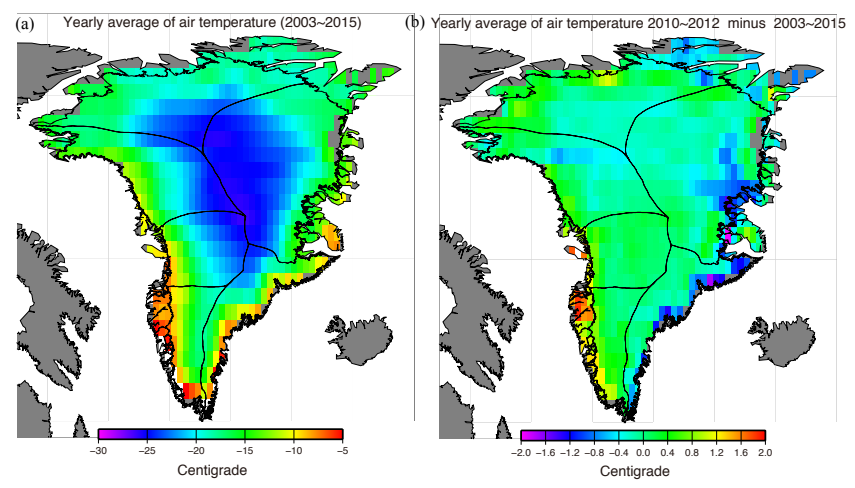

Figure 12. Average near-surface air temperatures from MODIS data in Greenland for the periods 2003-2015 (a) and 2010-2012 after removing the average of 2003 -2015 (b).

499

In response to positive near-surface temperature anomalies in the years 2010 and 2012, the GRACE and SMB results show accelerated mass loss (Figure 7). In previous studies, Nghiem et al. (2012) and Hall et al. (2013) already described the major melt event in 2012 in details, which was captured by ice melt maps from three different satellite missions. Seasonal and interannual variations in GRACE time series are qualitatively well reproduced including the large summer mass losses in 2010 and 2012 (van den Broeke et al., 2016). In fact, near-surface air temperatures are most appropriate for making long-range predictions of ice melting caused by climate variability. Differences in mass loss between GRACE and SMB are partly attributed to differences in the temperature input of the SMB model. Although not demonstrated in this study, the use of corrected SMB inputs based on in situ data will provide more accurate results when SMB outputs (i.e., sum of mass fluxes towards and away from the surface ice sheets) are used to refine the vertical and horizontal resolutions of GRACE. In turn, this reduces the uncertainty in the GRACE-based estimates of mass changes from ice sheets.

\subsection{Contribution of GrIS to sea level change}

It is well-known that global mean sea level variations are dominated by thermal 
The Cryosphere Discuss., https://doi.org/10.5194/tc-2018-142

Manuscript under review for journal The Cryosphere

Discussion started: 7 August 2018

(c) Author(s) 2018. CC BY 4.0 License.

expansion caused by heating of the global ocean, and variations of total ocean mass due to varying water mass fluxes from land to oceans. Here, we attempt to find the contribution of the GrIS to present-day global mean sea level rise. As shown in Figure 13 , the sum of ocean mass variations from GRACE-derived total land contributions and steric sea level from the total steric sea level anomaly data are close to the observed sea level trend of $3.3 \mathrm{~mm} / \mathrm{yr}$ derived from sea surface height anomaly data. The trend rate of the contributions of the total land (without Greenland), GrIS and steric sea level changes are $1.1 \mathrm{~mm} / \mathrm{yr}, 0.7 \mathrm{~mm} / \mathrm{yr}$ and $1.4 \mathrm{~mm} / \mathrm{yr}$, respectively.

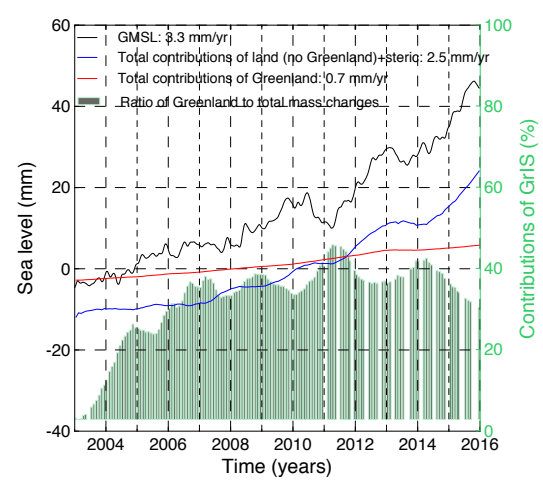

Figure 13. Global mean sea level (GMSL) from altimetry during 2003-2015 (black line), total freshwater input from land (without Greenland) and steric sea level changes (blue line), and GrIS contribution (red line). Seasonal signals have been removed. The grey vertical bars show the contribution rate of GrIS to the total mass change (when GRACE data are available).

526 It is important to note that a V-shaped or solitary wave sea level change is observed 527 from 2010 to 2012 (black line in Figure 13), which is mainly caused by terrestrial 528 water storage anomalies (blue line in Figure 13) related to the 2010/2011 La Niña 529 event (Boening et al., 2012; Fasullo et al., 2013). The GrIS is an important contributor to present-day global mean sea level rise. The average contribution rate (ratio of GrIS to the total mass change) is about $31 \%$. Furthermore, there is a clear acceleration of 
The Cryosphere Discuss., https://doi.org/10.5194/tc-2018-142

Manuscript under review for journal The Cryosphere

Discussion started: 7 August 2018

(c) Author(s) 2018. CC BY 4.0 License.

532 the proportion of melting in Greenland (grey vertical bars). It might be stressed that

533 the contribution of GrIS experienced an opposite V-shaped change during 2010-2012,

534 i.e., the sea level changes from rising to falling. This result indicates that increased

535 melting of GrIS partially compensated the sea level drop, which was due to a

536 temporary shift of water from the ocean to continents.

537

5385 Conclusions

539 In this study, the GrIS variations estimated from GRACE gravity fields and SMB data

540 have been investigated with respect to ice melting of Greenland and its contributions

541 to sea level changes. The spatial pattern of both long-term mass trends obtained from

542 monthly GRACE data and SMB indicates that the ice loss appears clearly over

543 drainage basins in different spatial scales and different time spans. Specifically during

544 the warm period 2010 to 2012, an anomalous acceleration of mass loss occurs in the

545 entire southern and western regions of GrIS, which reflects the major melt event due

546 to higher near-surface temperatures. We calculated time series for six sub-regions

547 defined by mascons using the least squares mascon fitting approach.

548 We found that the GrIS changes from the extended mascons solutions combined with

549 the matrix scaling factor method are in good agreement with previous studies. The

550 rate of the mass loss obtained by scaled GRACE and SMB is $-288 \pm 7 \mathrm{Gt} / \mathrm{yr}$ and -

$551275 \pm 1 \mathrm{Gt} / \mathrm{yr}$, respectively, from 2003 to 2015. The magnitude of this trend increased

552 significantly to $-456 \pm 30 \mathrm{Gt} / \mathrm{yr}$ in GRACE and $-464 \pm 38 \mathrm{Gt} / \mathrm{yr}$ in SMB in the period

553 2010-2012. The residuals obtained from GRACE after removing SMB may reflect

554 the contribution from glacial dynamics to total ice mass changes. These spatial

555 differences in the residuals among six drainage basins are in good agreement with the

556 surface elevation change rates previously derived from the ICESat data.

557 We computed SLF due to the ice mass fluxes of Greenland for the time period 2003-

558 2015. RSL anomalies caused by dynamics of the GrIS are not uniformly distributed

559 across the global oceans due to self-attraction and loading effects. Mass loss of the 
The Cryosphere Discuss., https://doi.org/10.5194/tc-2018-142

Manuscript under review for journal The Cryosphere

Discussion started: 7 August 2018

(c) Author(s) 2018. CC BY 4.0 License.

GrIS induces reduction of RSL at most coasts of Scandinavia and Northern Europe

561 (up to about $-0.6 \mathrm{~cm} / \mathrm{yr}$ ), In contrast, RSL rise is concentrated around South

562 America. The contribution ratio of GrIS to total sea level rise increased and the

563 average contribution rate was about $31 \%$ from 2003 to 2015. Although the

564 contribution of GrIS has an opposite V-shaped change relative to the sea level changes

565 during 2010-2012, it could not compensate completely the mass transfer from

566 oceans to the continents.

567 We also assessed a potential impact of the spherical harmonic truncation, spatial

568 averaging of mascon fitting and leakages from other time-dependent signals. The

569 sensitivity kernels for all extended mascons indicate that the sum of kernels is

570 well-localized to their regions and increased the weight of the boundary of GrIS. This

571 study suggests that the rescaled GrIS time series based on a uniform distribution

572 within the basin can effectively reduce the uncertainty caused by non-uniform mass

573 distribution of continental and oceanic areas. However, contributions of leakage

574 effects from outside ice sheets and the eustatic sea level to the total mass errors cannot

575 be avoided when using extended mascons. These factors likely limit the accuracy of

576 the estimated GrIS contributions to sea level changes.

577

578 Code and Data availability. The GRACE solutions used in this study are available

579 from CSR (ftp://podaac.jpl.nasa.gov/allData/grace/L2/CSR/RL05/) and the

580 GLDAS/Noah model data is provided by the NASA Goddard Earth Sciences Data and

581 Information Services Center (http://disc.sci.gsfc.nasa.gov/). Prof. Michiel R. van den

582 Broeke for providing RACMO v2.1 and v2.3 SMB fields over Greenland produced by

583 the Institute for Marine and Atmospheric Research

584 (https://www.projects.science.uu.nl/iceclimate/models/). Vishwakarma et al. (2017)

585 for providing the MATLAB implementation of the data-driven approach at:

586 http://www.gis.uni-stuttgart.de/research/projects/DataDrivenCorrection/. The global

587 mean sea level data was downloaded from NASA 
The Cryosphere Discuss., https://doi.org/10.5194/tc-2018-142

Manuscript under review for journal The Cryosphere

Discussion started: 7 August 2018

(c) Author(s) 2018. CC BY 4.0 License.

(https://sealevel.nasa.gov/understanding-sea-level/key-indicators/global-mean-sea-lev providing advice and sharing data and code where possible.

593

594 Central Universities, China University of Geosciences (Wuhan).

607 discussion of the results and revising the manuscript.

Competing interests. The authors declare that they have no conflict of interest.

\section{References} in Antarctica and Canada, Geophys. J. Int., 192, 557-572, 2013. 4965-497, 2017.

Author Contributions. Linsong Wang conceived the original experiments, performed the main data processing and analysis; Liangjing Zhang helped with the data processing and improve the experiment; Linsong Wang wrote the manuscript; Liangjing Zhang, Chao Chen, Maik Thomas and Mikhail Kaban contributed to the

Acknowledgments. We are grateful to Prof. Michiel R. van den Broeke for providing SMB model data. We also thank Dr. Vishwakarma for giving us more help to use the code. This work is supported by the National Natural Science Foundation of China (41504065, 41574070 and 41604060) and the Fundamental Research Funds for the

A, G. R., Wahr, J. and Zhong, S.: Computations of the viscoelastic response of a 3-D compressible Earth to surface loading: An application to Glacial Isostatic Adjustment

Adhikari, S., Ivins, E. R. and Larour, E.: Mass transport wave samplified by intense Greenland melt and detected in solid Earth deformation, Geophys. Res. Lett., 44,

Bamber, J. L., Layberry, R. L. and Gogineni, S. P.: A new ice thickness and bed data 
The Cryosphere Discuss., https://doi.org/10.5194/tc-2018-142

Manuscript under review for journal The Cryosphere

Discussion started: 7 August 2018

(c) Author(s) 2018. CC BY 4.0 License.

616 set for the Greenland ice sheet: 1. Measurement, data reduction, and errors, J.

617 Geophys. Res. Atmospheres, 106, 33773-33780, 2001.

618 Bamber, J. L., Riva, R. E., Vermeersen, B. L. and LeBrocq, A. M.: Reassessment of

619 the potential sea-level rise from a collapse of the West Antarctic Ice Sheet, Science,

$620324,901-903,2009$.

621 Beckley, B. D., Callahan, P. S., Hancock, D. W., Mitchum, G. T. and Ray, R. D.: On

622 the "Cal-Mode" Correction to TOPEX Satellite Altimetry and Its Effect on the Global

623 Mean Sea Level Time Series, J. Geophys. Res. Oceans, 122, 8371-8384, 2017.

624 Boening, C., Willis, J. K., Landerer, F. W., Nerem, R. S. and Fasullo, J.: The 2011 La

625 Niña: So strong, the oceans fell, Geophys. Res. Lett., 39, L19602, 2012.

626 Bolch, T., Sandberg Sørensen, L., Simonsen, S. B., Mölg, N., Machguth, H., Rastner,

627 P. and Paul, F.: Mass loss of Greenland's glaciers and ice caps 2003-2008 revealed

628 from ICESat laser altimetry data, Geophys. Res. Lett., 40, 875-881, 2013.

629 Box, J. E., Fettweis, X., Stroeve, J. C., Tedesco, M., Hall, D. K. and Steffen K.:

630 Greenland ice sheet albedo feedback: Thermody-namics and atmospheric drivers, The

631 Cryosphere, 6, 593-634, 2012.

632 Cheng, M., Tapley, B. D. and Ries, J. C.: Deceleration in the Earth's oblateness, J.

633 Geophys. Res., 118, 740-747, 2013.

634 Dziewonski, A. M. and Anderson, D. L.: Preliminary reference Earth model, Phys.

635 earth planet. in., 25(4), 297-356, 1981.

636 Ettema, J., van den Broeke, M. R., van Meijgaard, E., van de Berg, W. J., Bamber, J.

637 L., Box, J. E. and Bales, R. C.: Higher surface mass balance of the Greenland ice

638 sheet revealed by high-resolution climate modeling, J. Geophys. Res., 36, L12501,

6392009.

640 Farrell, W. E.: Deformation of the Earth by surface loads, Rev. Geophys., 10, 761-797, 6411972.

642 Farrell, W. E. and Clark, J. A.: On postglacial sea level, Geophys. J. Int., 46, 647-667, 6431976. 
The Cryosphere Discuss., https://doi.org/10.5194/tc-2018-142

Manuscript under review for journal The Cryosphere

Discussion started: 7 August 2018

(c) Author(s) 2018. CC BY 4.0 License.

644 Fasullo, J. T., Boening, C., Landerer, F. W. and Nerem, R. S.: Australia's unique

645 influence on global sea level in 2010-2011, Geophys. Res. Lett., 40, 4368-4373,

6462013.

647 Forsberg, R., Sørensen, L. and Simonsen, S.: Greenland and Antarctica ice sheet mass

648 changes and effects on global sea level, Surv. Geophys., 38, 89-104, 2017.

649 Gardner, A. S., Moholdt, G., Cogley, J. G. et al.: A reconciled estimate of glacier

650 contributions to sea level rise: 2003 to 2009, Science, 340, 852-857, 2013.

651 Hall, D. K., Comiso, J. C., DiGirolamo, N. E., Shuman, C. A., Box, J. E. and Koenig,

652 L. S.: Variability in the surface temperature and melt extent of the Greenland ice sheet

653 from MODIS, Geophys. Res. Lett., 40, 2114-2120, 2013.

654 Hanna, E., Huybrechts, P., Cappelen, J., Steffen, K., Bales, R. C., Burgess, E.,

655 McConnell, J. R., Steffensen, J. P., Van den Broeke, M., Wake, L., Bigg, G., Griffiths,

656 M. and Savas, D.: Greenland Ice Sheet surface mass balance 1870 to 2010 based on

657 Twentieth Century Reanalysis, and links with global climate forcing, J. Geophys. Res.,

658116, D24121, 2011.

659 Howat, I. M., Smith, B. E., Joughin, I. and Scambos, T. A.: Rates of southeast

660 Greenland ice volume loss from combined ICESat and ASTER observations, Geophys.

661 Res. Lett., 35, L17505, 2008.

662 Hurkmans, R. T. W. L., Bamber, J. L., Davis, C. H., Joughin, I. R., Khvorostovsky, K.

663 S., Smith, B. S. and Schoen, N.: Time-evolving mass loss of the Greenland Ice Sheet

664 from satellite altimetry, The Cryosphere, 8, 1725-1740, 2014.

665 Jacob, T., Wahr, J., Pfeffer, W. T. and Swenson, S.: Recent contributions of glaciers

666 and ice caps to sea level rise, Nature, 482, 514-518, 2012.

667 Jentzsch G.: Earth tides and ocean tidal loading, Tidal phenomena, Springer Berlin

668 Heidelberg, 66: 145-171, 1997.

669 Khan, S. A., Wahr, J., Bevis, M., Velicogna, I. and Kendrick, E.: Spread of ice mass

670 loss into northwest Greenland observed by GRACE and GPS, Geophys. Res. Lett., 37 ,

671 L06051, 2010. 
The Cryosphere Discuss., https://doi.org/10.5194/tc-2018-142

Manuscript under review for journal The Cryosphere

Discussion started: 7 August 2018

(c) Author(s) 2018. CC BY 4.0 License.

672 Liu, L., Khan, S. A., van Dam, T., Ma, J. H. Y. and Bevis, M.: Annual variations in

673 GPS-measured vertical displacements near Upernavik Isstrøm (Greenland) and

674 contributions from surface mass loading, J. Geophys. Res. Solid Earth, 122, 677-691,

6752017.

676 Lythe, M. B. and Vaughan, D. G.: BEDMAP: A new ice thickness and subglacial

677 topographic model of Antarctica, J. Geophys. Res. Solid Earth, 106, 11335-11351,

6782001.

679 Milne, G. A., Mitrovica, J. X. and Davis, J. L.: Near-field hydro-isostasy: The 680 implementation of a revised sea-level equation, Geophys. J. Int., 139, 464-482, 1999.

681 Mitrovica, J. X., Tamisiea, M. E., Davis, J. L. and Milne, G. A.: Recent mass balance

682 of polar ice sheets inferred from patterns of global sea-level change, Nature, 409, 683 1026-1029, 2001.

684 Nghiem, S. V., Hall, D. K., Mote, T. L., Tedesco, M., Albert, M. R., Keegan, K.,

685 Shuman, C. A., DiGirolamo, N. E. and Neumann, G.: The extreme melt across the

686 Greenland ice sheet in 2012, Geophys. Res. Lett., 39, L20502, 2012.

687 Noël, B., van de Berg, W. J., Machguth, H., Lhermitte, S., Howat, I., Fettweis, X. and

688 Van Den Broeke, M. R.: A daily, $1 \mathrm{~km}$ resolution data set of downscaled Greenland 689 ice sheet surface mass balance (1958-2015), The Cryosphere, 10, 2361-2377, 2016.

690 Noël, B., van de Berg, W. J., van Wessem, J. M., et al.: Modelling the climate and

691 surface mass balance of polar ice sheets using RACMO2-Part 1: Greenland (1958-

692 2016), The Cryosphere, 12, 811-831, 2018.

693 Peltier, W. R. and Andrews, J. T.: Glacial-Isostatic Adjustment-I. The Forward 694 Problem, Geophys. J. Int., 46, 605-646, 1976.

695 Rignot, E., Velicogna, I., van den Broeke, M. R., Monaghan, A. and Lenaerts, J.:

696 Acceleration of the contribution of the Greenland and Antarctic ice sheets to sea level

697 rise, Geophys. Res. Lett., 38, L05503, 2011.

698 Rodell, M., Houser, P. R., Jambor, U., Gottschalck, J., Mitchell, K., Meng, C. J., 699 Arsenault, K., Cosgrove, B., Radakovich, J., Bosilovich, M., et al.: The Global Land 
The Cryosphere Discuss., https://doi.org/10.5194/tc-2018-142

Manuscript under review for journal The Cryosphere

Discussion started: 7 August 2018

(c) Author(s) 2018. CC BY 4.0 License.

Data Assimilation System, Bull. Am. Meteorol. Soc., 85, 381-394, 2004.

701 Rodell, M., Velicogna, I. and Famiglietti, J. S.: Satellite-based estimates of

702 groundwater depletion in India, Nature, 460, 999-1002, 2009.

703 Schrama, E. J., Wouters, B. and Rietbroek, R.: A mascon approach to assess ice sheet

704 and glacier mass balances and their uncertainties from GRACE data, J. Geophys. Res.

705 Solid Earth, 119, 6048-6066, 2014.

706 Shepherd, A., Ivins, E. R., Geruo, A., et al.: A reconciled estimate of ice-sheet mass

707 balance, Science, 338, 1183-1189, 2012.

708 Sutterley, T. C., Velicogna, I., Csatho, B., van den Broeke, M., Rezvan-Behbahani, S.

709 and Babonis, G.: Evaluating Greenland glacial isostatic adjustment corrections using

710 GRACE, altimetry and surface mass balance data, Environ. Res. Lett., 9, 014004,

7112014.

712 Swenson, S., Chambers, D. and Wahr, J.: Estimating geocenter variations from a

713 combination of GRACE and ocean model output, J. Geophys. Res., 113, B08410,

7142008.

715 Swenson, S. and Wahr, J.: Methods for inferring regional surface- mass anomalies

716 from Gravity Recovery and Climate Experiment (GRACE) measurements of

717 time-variable gravity, J. Geophys. Res., 107, 2193, 2002.

718 Syed, T. H., Famiglietti, J. S., Rodell, M., Chen, J. and Wilson, C. R. Analysis of

719 terrestrial water storage changes from GRACE and GLDAS, Water Resour. Res., 44,

720 W02433, 2008.

721 Tamisiea, M. E., Hill, E. M., Ponte, R. M., Davis, J. L., Velicogna, I. and Vinogradova,

722 N. T.: Impact of self-attraction and loading on the annual cycle in sea level, J.

723 Geophys. Res. Oceans, 115, C07004, 2010.

724 Tapley, B. D., Bettadpur, S., Ries, J. C., Thompson, P. F and Watkins, M. M.: GRACE

725 measurements of mass variability in the Earth system, Science, 305, 503-505, 2004.

726 Van Angelen, J. H., Van den Broeke, M. R., Wouters, B. and Lenaerts, J. T. M.:

727 Contemporary (1960-2012) evolution of the climate and surface mass balance of the 
The Cryosphere Discuss., https://doi.org/10.5194/tc-2018-142

Manuscript under review for journal The Cryosphere

Discussion started: 7 August 2018

(c) Author(s) 2018. CC BY 4.0 License.

728 Greenland ice sheet, Surv. Geophys., 35, 1155-1174, 2014.

729 Van den Broeke, M., Bamber, J., Ettema, J., Rignot, E., Schrama, E., van de Berg, W.

730 J., van Meijgaad, E., Velicogna, I. and Wouters, B.: Partitioning recent Greenland

731 mass loss, Science, 326, 984-986, 2009.

732 Van den Broeke, M. R., Enderlin, E. M., Howat, I. M. and Noël, B. P.: On the recent

733 contribution of the Greenland ice sheet to sea level change, The Cryosphere, 10,

734 1933-1946, 2016.

735 Velicogna, I., Sutterley, T. C. and van den Broeke, M. R.: Regional acceleration in ice

736 mass loss from Greenland and Antarctica using GRACE time-variable gravity data, J.

737 Geophys. Res. Space Physics, 41, 8130-8137, 2014

738 Velicogna, I. and Wahr, J.: Acceleration of Greenland ice mass loss in spring 2004,

739 Nature, 443, 329-331, 2006.

740 Velicogna, I. and Wahr, J. Time-variable gravity observations of ice sheet mass

741 balance: Precision and limitations of the GRACE satellite data, Geophys. Res. Lett.,

$74240,3055-3063,2013$.

743 Vishwakarma, B. D., Devaraju, B. and Sneeuw, N.: Minimizing the effects of filtering

744 on catchment scale GRACE solutions, Water Resour. Res., 52, 5868-5890, 2016.

745 Vishwakarma, B. D., Horwath, M., Devaraju, B., Groh, A. and Sneeuw, N.: A

746 data-driven approach for repairing the hydrological catchment signal damage due to

747 filtering of GRACE products, Water Resour. Res., 53, 9824-9844, 2017.

748 Zwally, H. J., Li, J., Brenner, A. C., Beckley, M., Cornejo, H. G., DiMarzio, J.,

749 Giovinetto, M. B., Neumann, T. A., Robbins, J., Saba, J. L., Yi, D. H.and Wang, W. L.:

750 Greenland ice sheet mass balance: distribution of increased mass loss with climate

751 warming: 2003-07 versus 1992-2002, J. of Glaciology, 57, 88-102, 2011. 